\title{
A Study Of Corporate Venturing And Sustainability Of First Mover Advantages During Technological Disruption In The U.S. Mobile Wireless Data Industry
}

Ronald M. Rivas, (E-mail: rivasr@canisius.edu), Canisius College

\begin{abstract}
This study tests the impact of corporate venturing (CV) forms on the sustainability of pioneering advantage. Using the Miles and Covin 2002 classification of CV forms, this study shows that performance of early entrants is twice as much higher than performance of lagers. However, the effect of parent support prior to entry is substantially larger than the pioneering effect. Companies entering a market via direct external CV perform twenty five to fifteen times better than companies entering via direct internal $C V$. Hence, the sustainability of first mover advantage is challenged in the face of new entrants with superior resources.
\end{abstract}

Key Words: Strategic Management, Corporate Venturing, Disruptive Technology, First Mover Advantage, Mobile Business Strategies. Corporate Entrepreneruship

\section{INTRODUCTION}

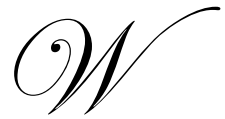

hat is the impact of the "parent-venture" corporate venturing relationship on the sustainability of first mover advantage during technological disruptions? One of the most active research areas in recent years is the study of how firms act and respond to technological change in a global economy. Corporate Venturing both internal and external to the company has become a significant strategic choice to speed up market entry. Corporate venturing (CV) is a means of creating new organizations from within the firm, or acquiring them, or engaging in complex alliances for the purpose of market entry (Miles \& Covin, 2002). The analysis of the strategic relationship between the parent company and the new venture is an essential part of corporate venturing (Sharma \& Chrisman, 1999; Thornhill \& Amit, 2001). In addition, understanding the timing of entry and the resource background of new entrant firms is crucial for the success of corporate venturing (Teng, 2007) in particular during disruptive technologies (Tino, 2006).

First mover advantages are often cited for performance achieved by pioneering firms entering into new markets (Lieberman, 1988). However, first mover disadvantages can also arise due to the challenges that pioneers have when entering into new markets (Boulding \& Christen, 2003). The resource base of competing firms often is a critical factor on determining whether a firm materializes first mover or late entrant advantages (Lieberman \& Montgomery, 1998). The case of the wireless data industry offers a particular opportunity for studying the strategic parent-venture relationship from the perspective of corporate venturing during technological disruption and its impact on sustainability of first mover advantage.

The mobile wireless data industry is revolutionizing the telecommunications field. Disruptive technologies are bringing e-commerce down from the PC-screen (hence, the few) to the car-driving or street-walking individual (hence the multitude). The two-way-communication mobile-internet-device (phone/PDA) with a geographicpositioning-system (GPS) facilitates a wide variety of m-Commerce strategies such as suggestive-marketing or on- 
line tracking, among others, based on the customer's location within the network and corresponding consumer behavior (Okazaki, 2007). Important strategic implications of mobile technology are improved working process; increased internal communication and knowledge sharing; and enhanced sales and marketing effectiveness (Sheng, Nah, \& Siau, 2005). The mobile wireless data industry is growing at an explosive pace especially in Europe and Asia. Standards such as WAP and Bluetooth are favoring convergence among different wireless networks, applications, and vendors. This will lead to a single technological platform with worldwide market opportunities. Hence understanding first-movers advantage in the mobile wireless world is of tremendous importance for practitioners wanting to take the market opportunities, and for academics willing to research new phenomena still to emerge in the upcoming $\mathrm{m}$ Business world.

Although there is significant theorizing clarifying the domain of $\mathrm{CV}$, there is nevertheless a need to examine what is the strategic relationship between CV and firm performance (Covin \& Miles, 2007; McGrath, Keil, \& Tukiainen, 2006). An area that has not received much attention in CV research is the effectiveness of CV under technological disruptions. There is evidence of the impact of $\mathrm{CV}$ and firm performance under dynamic high-technology markets (Christensen, 1997) in particular in disruptive technologies in Silicon Valley (Ferrary, 2003). However, the understanding of whether a parent company might yield superior performance to a new venture under technological disruption is limited. A technological disruption (Christensen, 1997) is a period of rapid industry transformation characterized by the introduction and adoption of new technologies resulting in the rise of new entrants and the obsolescence of incumbents (Danneels, 2004). Hence, this study contributes to the understanding of the CV parentventure strategic relationship on firm performance during technological disruptions in the wireless data industry. The main goal of this study is to propose a model of CV and sustainability of firm performance under technological disruption. A specific objective of this study is to examine and test whether the strategic parent-venture relationship yield superior performance during entry and if so, how it affects the sustainability of first mover advantages on an industry under technological disruption such as the mobile wireless data industry. This study begins by briefly reviewing the CV literature and proposing the model of $\mathrm{CV}$ and firm performance under technological disruption. It follows a brief description of the technological disruption of the mobile wireless data industry from 1996 to 2007 . Then it proceeds with an application of regression analysis with pooled data. Tests assessed the impact of CV on firm performance after entry on the mobile wireless data industry. It concludes with a discussion of results.

\section{THEORETICAL BACKGROUND}

Miles and Covin (2002) proposed that corporate venturing need to differentiate by focus of entrepreneurship and presence of investment intermediation. Corporate venturing could be internal or external to the corporation. Internal CV occurs when an established firm invest and or create new business (Sharma \& Chrisman, 1999). External CV involves investments that facilitate the founding of a business outside the parent company. In addition, CV could be funded either by direct investment in the venture through the corporations operating strategic budget or by indirect investment in the venture using financial intermediaries. Research in the Silicon Valley suggests that CV could be a source of competitive advantage in disruptive technologies (Ferrary, 2003). Figure 1 (See figure below) shows this study's proposed typology of the impact of $\mathrm{CV}$ on firm performance during technological disruptions.

This study builds on the Miles and Covin (2002) typology of CV and on the call for re-examination of firm performance during disruptive technologies (Danneels, 2004). Disruptive technologies render established technologies obsolete and therefore destroy the value of the investments that incumbents have made in those technologies (Danneels, 2004). The model shown in Figure 1 suggests that a venture performance is determined by pioneering advantage, by whether the venture results from CV from a parent company, and by the type of CV that is either direct or indirect. The strategic use of these three dimensions should boost venture performance. 
Figure 1

Pioneering and Parent-Venture effect on Firm Performance during Technological Disruptions

\begin{tabular}{|c|c|c|c|c|}
\hline & \multicolumn{2}{|c|}{ Pioneering } & \multicolumn{2}{|c|}{ Non-Pioneering } \\
\hline CV forms & Parent & No-Parent & Parent & No-Parent \\
\hline $\begin{array}{l}\text { Direct- } \\
\text { Internal }\end{array}$ & $\begin{array}{l}\text { Parent company } \\
\text { diversifies into pioneer } \\
\text { technology through } \\
\text { internal venture. } \\
\text { Pioneering and the } \\
\text { support from the parent } \\
\text { company should yield } \\
\text { superior performance. }\end{array}$ & $\begin{array}{l}\text { New Company enters } \\
\text { market through via } \\
\text { innovation. Company } \\
\text { funds innovation with } \\
\text { operational budget. } \\
\text { Pioneering gives high } \\
\text { performance. }\end{array}$ & $\begin{array}{l}\text { Parent company } \\
\text { diversifies into } \\
\text { technology through } \\
\text { internal venture. Parent } \\
\text { company support should } \\
\text { yield high performance. }\end{array}$ & $\begin{array}{l}\text { New Company enters late } \\
\text { into new market via } \\
\text { innovation. Low } \\
\text { performance. }\end{array}$ \\
\hline $\begin{array}{l}\text { Indirect- } \\
\text { Internal }\end{array}$ & $\begin{array}{l}\text { Parent company pioneers } \\
\text { technology and funds a } \\
\text { pool of internal ventures } \\
\text { through financial } \\
\text { intermediaries such as } \\
\text { venture capital } \\
\text { companies. Performance } \\
\text { depends on alignment of } \\
\text { Parent company and } \\
\text { venture company to } \\
\text { capture pioneering } \\
\text { advantage. }\end{array}$ & & $\begin{array}{l}\text { Parent company funds a } \\
\text { pool of internal ventures } \\
\text { through financial } \\
\text { intermediaries such as } \\
\text { venture capital } \\
\text { companies. Performance } \\
\text { depends on alignment of } \\
\text { Parent company } \\
\text { support and/or venture } \\
\text { company support. }\end{array}$ & \\
\hline $\begin{array}{l}\text { Direct- } \\
\text { External }\end{array}$ & $\begin{array}{l}\text { Parent company pioneers } \\
\text { technology and either } \\
\text { spins-off new venture or } \\
\text { funds external venture } \\
\text { with operational budget. } \\
\text { Pioneering and the } \\
\text { support from the parent } \\
\text { company should yield } \\
\text { superior performance. }\end{array}$ & $\begin{array}{l}\text { Management from } \\
\text { venture capital company } \\
\text { initially supports } \\
\text { company. Pioneering } \\
\text { gives high performance. }\end{array}$ & $\begin{array}{l}\text { Parent company either } \\
\text { spins-off new venture or } \\
\text { funds external venture } \\
\text { with operational budget. } \\
\text { Parent company } \\
\text { support should yield } \\
\text { high performance. }\end{array}$ & $\begin{array}{l}\text { Management from } \\
\text { venture capital company } \\
\text { initially supports } \\
\text { company. Performance } \\
\text { depends on support } \\
\text { from venture capital } \\
\text { company. }\end{array}$ \\
\hline $\begin{array}{l}\text { Indirect- } \\
\text { External }\end{array}$ & $\begin{array}{l}\text { Parent company funds } \\
\text { external venture in } \\
\text { pioneer technology } \\
\text { through financial } \\
\text { intermediaries. } \\
\text { Performance depends } \\
\text { on Venture capital } \\
\text { company's support. }\end{array}$ & & $\begin{array}{l}\text { Parent company funds } \\
\text { external venture in } \\
\text { pioneer technology } \\
\text { through financial } \\
\text { intermediaries. } \\
\text { Performance depends } \\
\text { on Venture capital } \\
\text { company's support. }\end{array}$ & \\
\hline
\end{tabular}

The strategic use of internal CV of a starting company is the archetypical case of new market entry via innovation, where pioneering advantage is paramount. The case of the strategic use of external CV needs further elaboration. A relevant strategic use of external CV is to boost performance through corporate diversification. Covin and Miles (2007) suggest that the strategic use of CV is akin to the degree of which a parent company's technology and/or markets are related to the new venture (question 12, Table 2, page 191). A central proposition in corporate diversification theory suggests that diversification into related business yields superior performance (Rumelt, 1982). Although, despite nearly 30 years of academic research on the benefits of related diversification, there is still considerable disagreement about precisely how and when diversification can be used to build long-run competitive advantage (Markides \& Williamson, 1994). Adding to the controversy is the debate on the validity of some of the most widely measures of related diversification (Robins \& Wiersema, 2003). However, recent research suggests that related diversification yields superior performance when the diversification occurs into related technologies (Miller, 2006). Following such insights form corporate technological diversification, this study considers a strategic use of CV when the 
new venture occurs into a technology that is related to the main parent's technology domain. In such case of related CV, the larger magnitude of resources from a parent company would give its new venture an advantage over independent new companies. Three hypotheses emerge out of the preceding discussion.

Hypothesis 1: New companies pioneering with direct-CVs will have superior performance.

Hypothesis 2: Parent use of related direct-CV will yield a venture with superior performance.

Hypothesis 3: Ventures that are Parent supported direct-external CVs will have higher performance than ventures entering via direct-internal $\mathrm{CV}$ will have.

After 1996, software companies rushed to build e-business platforms to support "Business to Consumers (B2C)" and "Business to Business (B2B) commercial interactions over the internet. In addition, after the deregulation of telecommunications of 1996, competition among telecommunication companies intensified and many companies ventured into the wireless telecommunication business segment. A new market emerged between 1998 and 2000 for companies that supplied m-business (mobile business) platforms for interactions over the internet by using wireless telecommunication technologies (Kumar \& Zahn, 2003). A process of consolidation occurred after the corporate scandals of 2002, continuing well until 2007. Thus, the ideal period in the emerging market of the wireless data industry to study CV into this disruptive technology is between 1998 and 2002. This period includes the period of entrance by new entrepreneurs to the m-business software platforms for wireless applications (1998-2002) and excludes the period of corporate consolidation brought up by the technology corporate scandals (2003-2007).

\section{METHODS}

This paper employs a two-pronged approach to test the impact of parent and time of entry on CV performance: 1) An OLS regression, and 2) A heuristic approach that groups companies according time of entry. The first approach employs three regression models to discern the impact of the pioneering and parent effects. The second approach consists in applying paired Student t-tests to evaluate how large and how significant are the differences among populations of early and late entrants. We pool the sample of companies from wireless and infrastructure software.

\section{Data}

We employ public data from Research Insight, Bloomberg, Hoovers, company annual reports, SEC filings, 10K and 10Q reports. We collected data from 1997 to 2000 during a period generally considered as the initial growth stage of the mobile wireless data industry. We tested the models for various years between 1997 and 2005. However, we present the analysis using Market capitalization at 2002. The year 2003 marks the beginning of a different strategic period in the industry, one of consolidation by mergers, acquisitions and attrition.

\section{Sample}

The sample comprises companies from two business segments that are interrelated into the supply chain of this industry. These companies are categorized as follows:

1. "Wireless Carriers" are companies that provide wireless telecommunication from customer to customer.

2. Mobile "Infrastructure software" are companies that provide the technology used to for e-business solutions and m-business solutions to deliver data over the internet via a wireless medium.

Table 1 shows the companies used in this study. Companies for the mobile software infrastructure segment were identified by content analysis of their company description, and product and operations description of Hoovers on line, and Bloomberg definition. The main author of this paper classified the companies by using Hoovers on line data. A research assistant performed a similar classification by using Bloomberg data. Both researchers compared the two 
classifications and the differences were resolved by reviewing the companies SEC filings. This procedure guarantees inter-rater reliability.

\section{Variables}

Variable include measures for the effect of pioneering and the effect of a parent company on CV. These variables measure venture performance, whether the venture was pioneering, whether the venture was launched by a larger parent company.

Dependent variable

Performance: Performance is measured as Market Capitalization as of 2002.

Independent variables

Time in Market (DAYS): This variable measures the number of days in the market since IPO up to December 2002.

Direct-External CV (PARENT): This is a Dummy variable (PARENT) that assigns a value of one (1) to any firm that had entered the market via direct-external CV. The Dummy variable PARENT assigns a value of zero (0) to any firm that entered the market via direct-internal CV (Companies without Parent).

\section{Control variables}

Industry: This is a Dummy variable that assigns a value of one (1) to any firm that is a wireless carrier. It assigns a value of zero (0) to any firm that is a mobile infrastructure software provider.

\section{Other classification variables}

Pioneering: Those companies that enter prior to 2000 were classified as pioneers. Given the relative short age of this industry, a threshold of two years of age since IPO as of December 2002 divides late from early entrants. Non-Pioneering. Late entrants are those companies that have less than two years (730 days since IPO).

\section{Empirical Methods}

Regressions analyses are used to assess the impact of pioneering and the effect of Parent on CV performance. These regressions were corrected for heteroscedasticity (using White-correcting method). Model 1 tests the impact of "Time in the Market" (DAYS) on Market capitalization on a pooled sample, controlling for industry group with a dummy variable. Model 2 tests the impact of "Time in the Market" (DAYS) and of "CV by parent company" (PARENT) on Market capitalization, also controlling for industry group. Finally, Model 3 tests the impact of "Time in the Market" on Market Capitalization while excluding the companies supported by a parent company prior to entry.

\section{RESULTS}

Figures 1 (shown below) shows the relative market value for each sub-group considering parent and pioneering effects. Table 1 (shown below) indicates the regressions results. 
Figure 1

CV forms and Pioneering Effects on Venture Value

(Relative Times of Average Market Capitalization)

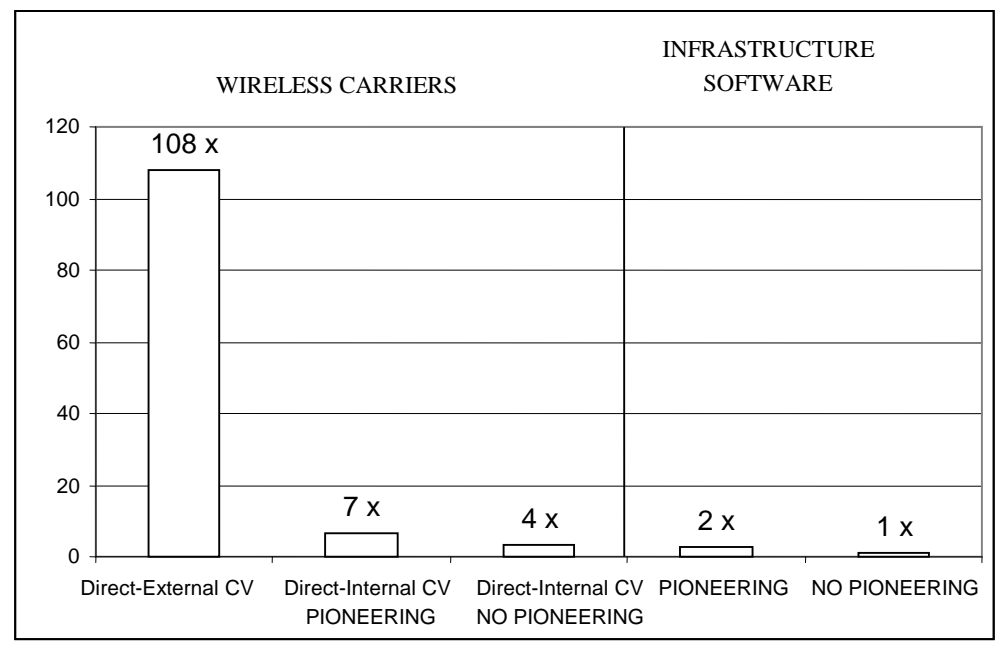

Table 1

Regressions of Time in Market and CV by Parent Company on Market Capitalization for Wireless carriers and Infrastructure software 2002

\begin{tabular}{|c|c|c|c|}
\hline & Model 1: & Model 2: & Model 3: \\
\hline & Pooled sample & $\begin{array}{c}\text { Pioneering } \\
\text { and External CV }\end{array}$ & Excluding external CV \\
\hline Intercept & 1179 & 1207 & 158 \\
\hline Time in Market & $(1869)$ & $(932)$ & $0.28 *$ \\
\hline Industry & -1.13 & $-1.17 *$ & $(0.13)$ \\
\hline & $(1.23)$ & $(0.60)$ & 259 \\
\hline Direct-External CV & $5162 *$ & 1677 & $(295)$ \\
\hline \multicolumn{2}{|c|}{$(2595)$} & $(1333)$ & - \\
\hline Adj. R square & - & $24656 * * *$ & 0.14 \\
\hline No. observations & - & 0.76 & 38 \\
\hline
\end{tabular}

From Figure 1 we observe that the mean of wireless carriers direct external CV is approximately 25 to 15 times larger than the mean of wireless carriers without a parent (108x vs. 7x or 4x). We also observe in Figure 1 that the mean value Market Capitalization for of pioneering wireless carriers is twice as large as the corresponding mean for nonpioneering wireless carriers ( $7 \mathrm{x}$ vs. $4 \mathrm{x})$. Table 1 shows the results from the three regression analyses. The main finding here is the remarkable impact of direct external CV on venture Market Capitalization. Model 1 shows that the effect of pioneering is not significant. Model 2 shows that the pioneering effect is negative and non-significant. The effect of direct-external CV is highly significant $(>0.001 \%)$. Finally, Model 3 shows that when we look only at direct internal CV (those companies that entered without parent), the pioneering effect is significant and with the correct sign. 


\section{DISCUSSION}

This study suggests that carriers benefit from first-mover advantages in a larger proportion than mobile infrastructure software companies do. However, the sustainability of such network based first-mover advantage is dynamic. As we observe in Model 2, the main factor determining performance among the wireless carriers is the form of corporate venturing namely direct-external CV. Model 2 shows that the support of a parent company prior to entry is significantly larger than pioneering. In fact, it is so important that early entrance might become a liability rather than a benefit. This suggests that pioneering advantage can be outpaced by resource-based advantages, such in this case, the support of a parent company. Resource abundant new entrants via direct-external CV could ride the technological wave initiated by pioneers without incurring in the discovery costs of an uncertain emerging industry. Nevertheless, in the absence of direct-external CV, pioneering via direct-internal CV seems to pay-off. Model 3 shows that once we remove those companies with parent support, pioneering becomes beneficial.

The main strategic competitive advantage that infrastructure software companies could develop is the "personalization" of the costumer profile combined with a two-way communication device with GPS. This feature could create network externalities by creating "communities" of users. Examples of these communities are appearing in Europe (such as the community of heart patients, which have obvious benefits of belonging to a mobile community in the case of a health emergency). Hence, the degree of "personalization" offered by a network could be a catalyst for company growth. If software companies can appropriate such source of competitive advantage then they might have a chance over the wireless carriers companies.

\section{Limitations And Suggestions For Future Research}

Several unanswered questions from this study create opportunities for further research including issues concerning the impact of resource profile on CV performance. A replication of these findings is needed on other industries that are as entrepreneurial as the wireless data industry. A longitudinal study of CV form that includes other non-market based measures of performance could be used to test the impact of resource profile on CV performance.

\section{REFERENCES}

1. Boulding, W. \& M. Christen. 2003. Sustainable pioneering advantage? Profit implications of market entry order. Marketing Science, 22(3): 371-92.

2. Christensen, Clayton M. 1997. Innovator's dilemma: When new technologies cause great firms to fail (hardcover). Harvard Business School Press Books: 1-255.

3. Covin, J. G. \& M. P. Miles. 2007. Strategic use of corporate venturing. Entrepreneurship Theory and Practice, 31(2): 183-207.

4. Danneels, Erwin. 2004. Disruptive technology reconsidered: A critique and research agenda. Journal of Product Innovation Management, 21(4): 246-58.

5. Ferrary, M. 2003. Managing the disruptive technologies life cycle by externalising the research: Social network and corporate venturing in the silicon valley. International Journal of Technology Management, 25(1-2): 165-80.

6. Kumar, S. \& C. Zahn. 2003. Mobile communications: Evolution and impact on business operations. Technovation, 23(6): 515-20.

7. Lieberman, M., \& Montgomery, D. 1988. First-mover advantages. Strategic Management Journal, 9: 4158 .

8. Lieberman, Marvin B. \& David B. Montgomery. 1998. First-mover (dis)advantages: Retrospective and link with the resource-based view. Strategic Management Journal, 19(12): 1111-25.

9. Markides, Constantinos C. \& Peter J. Williamson. 1994. Related diversification, core competences and corporate performance. Strategic Management Journal, 15(5): 149-65.

10. McGrath, R. G., T. Keil, \& T. Tukiainen. 2006. Extracting value from corporate venturing. MIT Sloan Management Review, 48(1): 50-+. 
11. Miles, Morgan P. \& Jeffrey G. Covin. 2002. Exploring the practice of corporate venturing: Some common forms and their organizational implications. Entrepreneurship: Theory \& Practice, 26(3): 21-40.

12. Miller, Douglas J. 2006. Technological diversity, related diversification, and firm performance. Strategic Management Journal, 27(7): 601-19.

13. Okazaki, S. 2007. Lessons learned from i-mode: What makes consumers click wireless banner ads? Computers in Human Behavior, 23(3): 1692-719.

14. Robins, James A. \& Margarethe F. Wiersema. 2003. The measurement of corporate portfolio strategy: Analysis of the content validity of related diversification indexes. Strategic Management Journal, 24(1): 39.

15. Rumelt, Richard P. 1982. Diversification strategy and profitability. Strategic Management Journal, 3(4): 359-69.

16. Sharma, Pramodita \& James J. Chrisman. 1999. Toward a reconciliation of the definitional issues in the field of corporate entrepreneurship. Entrepreneurship: Theory \& Practice, 23(3): 11-27.

17. Sheng, H., F. F. H. Nah, \& K. Siau. 2005. Strategic implications of mobile technology: A case study using value-focused thinking. Journal of Strategic Information Systems, 14(3): 269-90.

18. Teng, B. S. 2007. Corporate entrepreneurship activities through strategic alliances: A resource-based approach toward competitive advantage. Journal of Management Studies, 44(1): 119-42.

19. Thornhill, Stewart \& Raphael Amit. 2001. A dynamic perspective of internal fit in corporate venturing. Journal of Business Venturing, 16(1): 25.

20. Tino, Michalski. 2006. Radical innovation through corporate entrepreneurship from a competence-based strategic management perspective. International Journal of Management Practice, 2(1): 22. 